\title{
Effect of Different Finishing and Polishing Techniques on the Surface Roughness of Microfilled, Hybrid and Packable Composite Resins
}

\author{
Silvia Helena BARBOSA ${ }^{1}$ \\ Régia Luzia ZANATA ${ }^{2}$ \\ Maria Fidela de Lima NAVARRO ${ }^{2}$ \\ Osvaldo Benoni NUNES ${ }^{3}$ \\ ${ }^{1}$ Faculty of Dentistry of São Jose dos Campos, UNESP, São Jose dos Campos, SP, Brazil \\ ${ }^{2}$ Faculty of Dentistry of Bauru, University of São Paulo, Bauru, SP, Brazil \\ ${ }^{3}$ Faculty of Dentistry of Lins, Lins, SP, Brazil
}

\begin{abstract}
This study examined the average surface roughness ( $\mathrm{Ra}, \mu \mathrm{m})$ of 2 microfilled (Durafill and Perfection), 1 hybrid (Filtek Z250) and 2 packable composite resins (Surefil and Fill Magic), before (baseline) and after eight different finishing and polishing treatments. The surface roughness was assessed using a profilometer. Ten specimens of each composite resin were randomly subjected to one of the following finishing/polishing techniques: A - carbide burs; B - fine/extrafine diamond burs; C - Sof-Lex aluminum oxide discs; D Super-Snap aluminum oxide discs; E - rubber polishing points + fine/extrafine polishing pastes; F - diamond burs + rubber polishing points + fine/extrafine polishing pastes; G - diamond burs + Sof-Lex system; H - diamond burs + Super-Snap system. Data were analyzed using two-way ANOVA and Tukey's HSD test. Significant differences $(\mathrm{p}<0.05)$ were detected among both the resins and the finishing/polishing techniques. For all resins, the use of diamond burs resulted in the greatest surface roughness (Ra: 0.69 to $1.44 \mu \mathrm{m}$ ). The lowest Ra means were obtained for the specimens treated with Sof-Lex discs (Ra: 0.11 to $0.25 \mu \mathrm{m}$ ). The Ra values of Durafill were lower than those of Perfection and Filtek Z250, and these in turn had lower Ra than the packable composite resins. Overall, the smoothest surfaces were obtained with the use the complete sequence of Sof-Lex discs. In areas that could not be reached by the aluminum oxide discs, the carbide burs and the association between rubber points and polishing pastes produced satisfactory surface smoothness for the packable and hybrid composite resins, respectively.
\end{abstract}

Key Words: surface roughness, composite resins, finishing and polishing.

\section{INTRODUCTION}

Proper finishing and polishing are important steps in clinical restorative dentistry that enhance both esthetics and longevity of restorations. Residual surface roughness may result in excessive plaque accumulation, gingival inflammation and increased surface staining (1-3). Additionally, surface roughness may directly influence the wear behavior and marginal integrity of posterior composite resin restorations $(4,5)$.

A wide variety of finishing and polishing devices have been investigated, including coated abrasives such as diamond burs and aluminum oxide or silicon carbide finishing discs. Bonded abrasives, i.e., rubber or silicone compounds, and several polishing pastes containing fine-particle-size abrasives have also been recommended for polishing of composite resins.

Procedural steps are based on the sequential application of progressively finer grits of an abrasive medium used in various types of instruments. Different finishing/polishing techniques and devices are available for the different categories of resin-based materials and types of restorations. For hybrid and microfilled composite resins, for example, aluminum oxide discs and rubber polishing systems have been suggested as the standard protocol $(3,5)$. On the other hand, the high fillerload and the novel matrix and filler formulations of packable composite resins have been shown to influ- 
ence their ability to be polished $(5,6)$.

There is limited evidence indicating which finishing/polishing techniques and materials would be the most effective for packable composite resins (5-10). Moreover, with heterogeneous materials, such as composite resins, smoothness of restorations is also influenced by the internal structure (size and arrangement of the filler content) because the resin matrix and the filler particles have different hardness and so do not abrade to the same degree (8). On account of this, it is likely that microfilled, hybrid and packable composite resins do not achieve a comparable surface smoothness even when submitted to the same procedural finishing and polishing techniques. Therefore, it would be of interest to investigate whether commercially available resinbased materials require different surface treatments.

This study evaluated the effect of various finishing/polishing techniques on the surface roughness ( $\mathrm{Ra}$, $\mu \mathrm{m})$ of different types of composite resins: two microfilled, one hybrid and two packable.

\section{MATERIAL AND METHODS}

Details of the commercially available composite resins used in this study are given in Table $1(8,10,11)$.

Eighty disc-shaped specimens of each resin were fabricated using a stainless steel split mould with a central hole (6 $\mathrm{mm}$ in diameter; $3 \mathrm{~mm}$ deep). Each composite resin was inserted into the mould in two increments of $1.5 \mathrm{~mm}$ each, covered with Mylar strip

Table 1. Tested materials ${ }^{\mathrm{a}}$.

\begin{tabular}{|c|c|c|c|c|}
\hline $\begin{array}{l}\text { Composite } \\
\text { resin }\end{array}$ & Type & $\begin{array}{l}\text { Particle size } \\
\qquad(\mu \mathrm{m})\end{array}$ & $\begin{array}{l}\text { Filler content } \\
\qquad(\%)\end{array}$ & Manufacturer \\
\hline Durafill & Microfilled & 0.04 & 37.5 (vol) & $\begin{array}{c}\text { Kulzer } \\
\text { Friedrichsdorf, Germany }\end{array}$ \\
\hline Perfection & Microfilled & 0.04 & 20 (vol) & $\begin{array}{c}\text { Den-Mat } \\
\text { Santa Maria, CA, USA }\end{array}$ \\
\hline Filtek Z250 & Hybrid & $0.01-3.5$ & 60 (vol); 78 (weight) & $\begin{array}{c}\text { 3M/ESPE } \\
\text { St. Paul, MN, USA }\end{array}$ \\
\hline Surefil & Packable & $0.8-20$ & 84 (weight); 60 (vol) & $\begin{array}{l}\text { LD Caulk/Dentsply } \\
\text { Milford, DE, USA }\end{array}$ \\
\hline Fill Magic & Packable & 0.50 & 80 (weight) & $\begin{array}{c}\text { Vigodent } \\
\text { Rio de Janeiro, RJ, Brazil }\end{array}$ \\
\hline
\end{tabular}

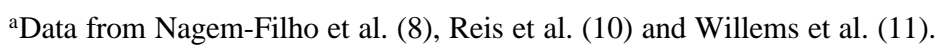

(Mylar Uni-Strip, LD Caulk/Dentsply, Milford, DE, USA) pressed flat using with a glass slide and lightcured with a curing light for $40 \mathrm{~s}$ (Curing Light XL3000; 3M Dental Products, St Paul, MN, USA). The output was checked using a curing radiometer (Demetron, Kerr, Basel, Switzerland) to ensure a light intensity of at least $600 \mathrm{~mW} / \mathrm{cm}^{2}$. The polymerized specimens were removed from the mould and stored in distilled water at $37^{\circ} \mathrm{C}$ for $24 \mathrm{~h}$.

Ten specimens of each composite resin were randomly assigned to one of the eight finishing/polishing techniques given in Table 2.

To reduce variability, specimen preparation, finishing and polishing procedures were carried out by the same operator. Diamond and carbide burs were applied using light pressure in a single direction that was previously traced onto the specimen surface. After application on five surfaces, a new bur was used. The aluminum oxide discs and the polishing rubber points were discarded after each use.

The baseline average surface roughness ( $\mathrm{Ra}$, $\mu \mathrm{m})$ was measured on each specimen immediately after light curing under the Mylar strip by means of a surface profilometer (Homme tester T 1000, Hommelwerke, Germany) with a 2- mm tracing length. The profilometer was accurate to $0.005 \mu \mathrm{m}$. Three tracings were recorded on each specimen perpendicular to the finishing and polishing scratch directions and the average of these three $\mathrm{Ra}$ measurements was determined as the final Ra score for each specimen. The effect of surface waviness was minimized by using a $0.8 \mathrm{~mm}$ cutoff.

New surface roughness readings of the specimens were carried out after each finishing/ polishing treatment to assess the differences between the baseline and the post-polishing Ra values.

Ra means and standard deviations were determined. Twoway ANOVA was done to compare differences with respect to material, finishing/polishing technique and interaction between both variables. Post-hoc comparison was done using Tukey's (HSD) test. Statistical significance was considered at 5\% level. 


\section{RESULTS}

Ra values $(\mu \mathrm{m})$ and standard deviations are presented in Table 3. The statistical analysis showed significant differences $(\mathrm{p}<0.05)$ among the composite resins for each finishing/polishing technique, as well as among the method of finishing/polishing techniques,

Table 2. Techniques and finishing/polishing procedures.

\begin{tabular}{cl}
\hline Technique & Finishing and Polishing Procedures \\
\hline A & $\begin{array}{l}\text { 12-fluted (FG 7214F) and 30-fluted (FG 9642FF) carbide finishing } \\
\text { burs (KG Sorensen Ind. e Com. Ltda, Barueri, SP, Brasil), } \\
\text { sequentially applied for 20 s each, using a water-cooled high speed } \\
\text { handpiece, moved in a single direction on the entire specimen } \\
\text { surface }\end{array}$ \\
& Fine (2135F) and extrafine (2135FF) diamond burs (KG Sorensen), \\
& applied in the same way as described for technique A \\
B & Sof-Lex aluminum oxide discs (3M/ESPE, St Paul, MN, USA) \\
& applied in progressively finer grits (coarse, medium, fine and \\
C & movements and without water-cooling, \\
& Super Snap aluminum oxide discs (Shofu, Kyoto, Japan) applied \\
in the same way as described for technique C & Polishing rubber points (8062, Viking; KG Sorensen) applied as \\
described for technique C plus application of fine and extrafine \\
polishing pastes (Prisma Gloss; LD Caulk/Dentsply) for 10 s each, \\
using a felt polishing disc \\
D \\
Diamond burs, applied as described for technique B, plus polishing \\
rubber points and polishing pastes, applied as described for \\
technique E. \\
Diamond burs applied as described for technique B, plus medium, \\
fine and extrafine Sof-Lexdiscs, applied as described for technique C \\
Diamond burs applied as described for technique B, plus medium, \\
fine and extrafine Super Snap discs, applied as described for \\
technique D.
\end{tabular}

within each composite resin group $(\mathrm{p}<0.05)$. Interactions between both factors were also detected detected $(\mathrm{p}<0.05)$.

The Mylar strip (baseline) had the lowest Ra values for all the composite resins tested (Table 4). Comparing the materials at baseline, it was observed that the microfilled composite resins had lower Ra values than the hybrid composite resin, which in turn had lower Ra value than the packable composite resins (Table 5). Tukey's post-hoc comparison by material revealed that the Ra values recorded for Durafill microfilled composite resin were lower than those recorded for Perfection microfilled and Filtek Z 250 hybrid composite resins, and these showed lower Ra than the packable composite resins. Comparing the eight finishing/ polishing techniques proposed (different combinations of burs, discs, rubber points and pastes), the smoothest surface was obtained with the use of the complete sequence of Sof-Lex aluminum oxide discs. The worst results were obtained after using the diamond burs alone.

\section{DISCUSSION}

Polyester matrix strips (baseline) produced the smoothest surfaces for all tested composite resins. The surface roughness values obtained were below the threshold $\mathrm{Ra}$ value of $0.2 \mu \mathrm{m}$ suggested by Bollen et al. (2) and are in agreement with the findings of previous studies $(8-10,12,13)$. At baseline, the statistically significant differences in surface rough-

Table 3. Ra means $(\mu \mathrm{m})$ and standard deviations (SD) recorded at baseline and after the finishing/polishing techniques.

\begin{tabular}{|c|c|c|c|c|c|c|c|c|c|}
\hline Composite & Baseline & A & B & $\mathrm{C}$ & D & $\mathrm{E}$ & $\mathrm{F}$ & G & $\mathrm{H}$ \\
\hline Durafill & $0.05 \pm 0.00$ & $0.38 \pm 0.05$ & $0.70 \pm 0.11$ & $0.11 \pm 0.04$ & $0.17 \pm 0.04$ & $0.29 \pm 0.11$ & $0.25 \pm 0.64$ & $0.18 \pm 0.07$ & $0.06 \pm 0.01$ \\
\hline Perfection & $0.05 \pm 0.00$ & $0.45 \pm 0.15$ & $0.69 \pm 0.13$ & $0.12 \pm 0.05$ & $0.14 \pm 0.04$ & $0.36 \pm 0.06$ & $0.27 \pm 0.05$ & $0.24 \pm 0.07$ & $0.14 \pm 0.01$ \\
\hline FiltekZ250 & $0.07 \pm 0.03$ & $0.48 \pm 0.08$ & $1.41 \pm 0.23$ & $0.11 \pm 0.07$ & $0.33 \pm 0.13$ & $0.49 \pm 0.13$ & $0.34 \pm 0.08$ & $0.19 \pm 0.03$ & $0.27 \pm 0.10$ \\
\hline Surefil & $0.13 \pm 0.06$ & $0.54 \pm 0.08$ & $1.40 \pm 0.43$ & $0.19 \pm 0.04$ & $0.25 \pm 0.05$ & $0.17 \pm 0.07$ & $0.62 \pm 0.08$ & $0.36 \pm 0.08$ & $0.23 \pm 0.04$ \\
\hline Fill Magic & $0.10 \pm 0.04$ & $0.52 \pm 0.11$ & $1.44 \pm 0.26$ & $0.25 \pm 0.06$ & $0.21 \pm 0.04$ & $0.64 \pm 0.14$ & $0.43 \pm 0.11$ & $0.20 \pm 0.05$ & $0.35 \pm 0.11$ \\
\hline
\end{tabular}

See Table 2 for definitions of finishing/polishing techniques. 
Table 4. Comparison of baseline and finishing/polishing techniques for each composite resin.

\begin{tabular}{ll}
\hline Composite resin & \multicolumn{1}{c}{ Technique } \\
\hline Durafill & Baseline, $\mathrm{E}<\mathrm{C}<\mathrm{D}, \mathrm{H}<\mathrm{G}<\mathrm{F}, \mathrm{A}<\mathrm{B}$ \\
Perfection & Baseline $<\mathrm{C}, \mathrm{D}, \mathrm{E}<\mathrm{H}<\mathrm{G}, \mathrm{F}, \mathrm{A}<\mathrm{B}$ \\
Filtek Z250 & Baseline $<\mathrm{C}<\mathrm{H}<\mathrm{E}, \mathrm{D}, \mathrm{G}, \mathrm{A}, \mathrm{F}<\mathrm{B}$ \\
Surefil & Baseline, $\mathrm{E}<\mathrm{C}, \mathrm{H}<\mathrm{D}, \mathrm{G}<\mathrm{A}<\mathrm{F}<\mathrm{B}$ \\
Fill Magic & Baseline $<\mathrm{H}, \mathrm{D}<\mathrm{C}<\mathrm{E}, \mathrm{G}<\mathrm{A}<\mathrm{F}<\mathrm{B}$ \\
\hline
\end{tabular}

See Table 2 for definitions of finishing/polishing techniques. Post-hoc comparison done using Tukey's (HSD) test.

Table 5. Comparison of the composite resins at baseline and after each finishing/polishing techniques.

\begin{tabular}{ll}
\hline Technique & \multicolumn{1}{c}{ Composite resin } \\
\hline Baseline & Perfection, Durafill $<$ Z250 < Fill Magic $<$ Surefil \\
A & Perfection, Durafill, Z250 < Surefil, Fill Magic \\
B & Perfection $<$ Durafill $<$ Z250, Surefil < Fill Magic \\
C & Perfection, Durafill, Z250 < Surefil < Fill Magic \\
D & Perfection < Durafill $<$ Fill Magic $<$ Surefil, Z250 \\
E & Durafill $<$ Perfection, Surefil < Z250, Fill Magic \\
F & Perfection, Durafill, Z250 < Surefil < Fill Magic \\
G & Durafill $<$ Perfection, Z250, Surefil, Fill Magic \\
H & Durafill $<$ Perfection, Z250, Surefil, Fill Magic
\end{tabular}

See Table 2 for definitions of finishing/polishing techniques. Post-hoc comparison done using Tukey's (HSD) test.

ness values found among the composite resins correlated well with the average particle size of each material $(4,5,14)$.

For the microfilled composite resins, the use of the complete sequence of aluminum oxide discs (techniques $\mathrm{C}$ and $\mathrm{D}$ ) resulted in the smoothest surfaces. The Sof-Lex system yielded better results than the Super Snap system for Durafill, but no significant differences were observed between both polishing systems for Perfection. The Ra values recorded for the hybrid and microfilled composite resins treated with techniques $\mathrm{C}$ and $\mathrm{D}$ are in agreement with the results of previous studies (15-17). The Ra values for the packable composite resins are also comparable to those reported by Ryba et al. (5), Reis et al. (10) and Özgünaltay et al. (9).

The aluminum oxide discs have been shown to produce better surface smoothness because they do not displace the composite fillers $(17,18)$. Berastegui et al. (16) reported that the fillers in microfilled composite resins are so small that their stiffness is reduced and therefore the aluminum oxide discs are best recommended because their malleability promotes a homogeneous abrasion of the fillers and the resin matrix.

On the other hand, Yap et al. (12) and Hoelscher et al. (13) obtained similar finishing using either aluminum oxide discs or abrasive points (Enhance) plus polishing pastes for microfilled composite resins. These authors $(12,13)$ attributed their results to the shape of the abrasive point utilized (discs), because the application of cup-shaped points might cause the filler displacement (19).

In this study, the use of burs yielded a remarkable increase in surface roughness of all composite resins evaluated, which is in agreement with the results of previous studies $(4,6,8,9,13,15)$. The Ra values obtained with diamond burs (technique B) were significantly greater than those obtained with the use of carbide burs (technique A) for all composite resins, which is consistent with the findings of other studies $(6,7,9,10,16-18)$. These results suggest that diamond burs (fine and extrafine) are instruments only recommended for initial countering of the restorations. In this study, after using diamond burs, finishing and polishing were complemented with application of rubber points, polishing pastes and different systems of aluminum oxide discs.

It was observed that, in specimens receiving surface treatment with diamond burs, the Super Snap system $(\mathrm{H})$ produced smoother surfaces than the SofLex system $(\mathrm{G})$ for all materials, suggesting a better ability of the Super-Snapdiscs to remove the scratches left by the diamond burs when compared to the Sof-Lex discs. On the other hand, the use of rubber points and polishing pastes after application of diamond burs (F) were much less efficient. The mean roughness values observed in technique $\mathrm{F}$ were numerically close to those obtained with the carbide burs (technique A) for the hybrid and microfilled composite resins. For packable composite resins, however, the application of rubber points and pastes had slight effect on the composite resin surface roughness.

Differences in roughness after finishing and polishing techniques may be ascribed to distinct patterns of particle size and their arrangement within the resin matrix $(5,6)$. For a composite finishing system to be rendered effective, the cutting particles must be harder than the filler particles, otherwise the abrasive medium 
may abrade the softer matrix and only round the filler particles. This may paradoxically result in higher surface roughness $(5,8,10)$. Therefore, the effectiveness of finishing/polishing procedures on contemporary packable composite surface may be more critical.

Nagem-Filho et al. (8) stated that different compositions of the particles and matrix of composite resins are not important in determining the surface roughness after use of diamond burs, probably due to the rough surface they produce.

In this study, the smoothness obtained on the packable composite specimens was similar to that observed for the hybrid composite resins and even for Perfection microfilled resin, when the $\mathrm{G}$ and $\mathrm{H}$ techniques were used. This suggests that aluminum oxide discs were able to enhance the finishing produced by the diamond burs.

The findings of the present study showed that flexible aluminum oxide discs yielded the lowest Ra values for microfilled, hybrid and packable composite resins, and may be accepted as a clinical standard for polishing composites. However, their use has limitations due to their geometry, being difficult to reach countered surfaces, especially in posterior restorations. In this study only flat surfaces were evaluated.

For all types of composite resins tested in this study, the use of carbide and diamond burs associated with rubber polishing points provided surface roughness means above the threshold Ra value suggested by Bollen et al (2), which is of clinical importance in bacterial retention. However, it is important to highlight that these treatments yielded Ra values below 0.65 $\mu \mathrm{m}$ and numerically close to enamel surface roughness in occlusal contact areas $(\mathrm{Ra}=0.64 \mu \mathrm{m})(12)$. In addition, these instruments produced satisfactory smoothness in areas that could not be reached by the aluminum oxide discs.

The application of carbide burs followed by rubber polishing points, although not investigated in this study, may provide even better results, especially for packable composite resins, as previously demonstrated (7).

\section{RESUMO}

Este estudo avaliou a rugosidade superficial $(\mathrm{Ra}, \mu \mathrm{m})$ de 2 resinas compostas microparticuladas (Durafill; Perfection), 1 híbrida (Filtek Z250) e 2 compactáveis (Surefil; Fill Magic), antes (baseline) e após a realização de 8 técnicas de acabamento e polimento. A rugosidade foi avaliada com rugosímetro. Dez espécimes de cada resina foram submetidos aos seguintes procedimentos: A - brocas cabide; $\mathrm{B}$ - pontas diamantadas fina/ extrafina; C - sistema Sof-Lex; D - sistema Super-Snap; E pontas de borracha + pastas de polimento; $\mathrm{F}$ - pontas diamantadas + pontas de borracha + pastas de polimento; G - pontas diamantadas + Sof-Lex; H - pontas diamantadas + Super-Snap. Os dados foram submetidos à análise de variância a dois critérios e teste de Tukey. Foi observada diferença estatisticamente significante $(\mathrm{p}<0.05)$ tanto entre as resinas compostas quanto entre as técnicas de acabamento/polimento. Para todas as resinas, a maior rugosidade foi produzida com o emprego das pontas diamantadas (Ra: 0.69-1.44 $\mu \mathrm{m}$ ). O menor valor de rugosidade foi obtido com o sistema Sof-Lex (Ra: 0.11- 0.25 $\mu \mathrm{m}$ ). A Durafill apresentou melhor lisura que a Perfection e a Z250, que apresentaram melhor lisura que as resinas compactáveis. A sequiência completa de discos Sof-Lex produziu a melhor lisura para todas as resinas. Em áreas sem acesso aos discos, as pontas de borracha e pastas de polimento produziram lisura de superfície satisfatória para as resinas híbridas enquanto as brocas carbide produziram polimento adequado para as resinas compactáveis.

\section{ACKNOWLEDGEMENTS}

The authors are grateful to FAPESP for scientific and financial support (grant 99/02647-2).

\section{REFERENCES}

1. Li Y, Swartz ML, Philips RW, Moore BK, Roberts RW. Effects of filler content and size on properties of composites. J Dent Res 1985;64:1396-1401.

2. Bollen CML, Lambrechts P, Quirynen M. Comparison of surface roughness of oral hard materials to the threshold surface roughness for bacterial plaque retention: a review of the literature. Dent Mater 1997;13:258-269.

3. Jefferies SR. The art and science of abrasive finishing and polishing in restorative dentistry. Dent Clin of North Am 1998;42:613627.

4. Reis AF, Giannini M, Lovadino JR, Dias CTS. The effect of six polishing systems on the surface roughness of two packable resinbased composites. Am J Dent 2002;15:193-197.

5. Ryba TM, Dun NWJ, Murchison DF. Surface roughness of various packable composites. Oper Dent 2002;27:243-247.

6. Jung M, Voit S, Klime K. Surface geometry of three packable and one hybrid composite after finishing. Oper Dent 2003;28:53-59.

7. Roeder LB, Tate WH, Powers JM. Effect of finishing and polishing procedures on the surface roughness of packable composites. Oper Dent 2000;25:534-543.

8. Nagem-Filho H, D'Azevedo MTFS, Nagem HD, Marsola FP. Surface roughness of composite resins after finishing and polishing. Braz Dent J 2003;14:37-41.

9. Özgünaltay G, Yazici AR, Görücü J. Effect of finishing and polishing procedures on the surface roughness of new toothcoloured restoratives. J Oral Rehabil 2003;30:218-224.

10. Reis AF, Giannini M, Lovadino JR, Ambrosano GM. Effects of various finishing systems on the surface roughness and staining susceptibility of packable composite resins. Dent Mater 
2003;19:12-18.

11. Willems G, Lambrechts P, Braem M, Celis JP, Vanherle G. A classification of dental composites according to their morphological and mechanical characteristics. Dent Mater 1992;8:310318.

12. Yap AUJ, Lye KW, Sau CW. Surface characteristics of toothcolored restoratives polished utilizing different polishing systems. Oper Dent 1997;22:260-265.

13. Hoelscher DC, Neme AML, Pink FE, Hughes PJ. The effect of three finishing systems on four esthetic restorative materials. Oper Dent 1998;23:36-42.

14. Kaplan BA, Goldstein GR, Vijayaraghavan TV, Nelson IK. The effect of three polishing systems on the surface roughness of four hybrid composites: a profilometric and scanning electron micros- copy study. J Prosthet Dent 1996;76:34-38.

15. Eide R, Tveit AB. Finishing and polishing of composites Acta Odontol Scand 1980;46:307-312.

16. Berastegui E, Canalda C, Brau E, Miquel C. Surface roughness of finished composite resins. J Prosthet Dent 1992;68:742749.

17. Chung K. Effects of finishing and polishing procedures on the surface texture of resin composites. Dent Mater 1994;10:325330.

18. Bouvier D, Duprez JP, Lissac M. Comparative evaluation of polishing systems on the surface of three aesthetic materials. J Oral Rehabil 1997;24:888-894.

19. Tate WH, Powers JM. Surface roughness of composites and hybrid ionomers. Oper Dent 1996;21:53-58.

Accepted November 29, 2004 